\title{
ПРОДУКТИВНІСТЬ КУРЧАТ-БРОЙЛЕРІВ ЗА ВВЕДЕННЯ У КОМБІКОРМ ДРІЖДЖІВ SACCHAROMYCES CEREVISIAE
}

\author{
Оріщук Оксана Сергіївна \\ кандидат сільськогосподарських наук, доцент \\ Дніпровський державний аграрно-економічний університет \\ ORCID: 0000-0002-6140-870X, \\ oksana.orishuk@gmail.com
}

Цап Світлана Володимирівна кандидат сільськогосподарських наук, доцент Дніпровський державний аграрно-економічний університет ORCID: 0000-0002-2495-949X tsap.svetlana@i.ua.

В даний час існує проблема отримання екологічно чистої продукції, що не приносить шкоди людині.

Протягом багатьох років основним засобом контролю кишкової мікрофлори птиці були кормові антибіотики. Однак, вони мають ряд суттєвих недоліків, зокрема, здатність до накопичення їх залишкових кількостей у продуктах птахівництва та розвитку стійкості й адаптації мікроорганізмів до даних препаратів у результаті їх тривалого застосування.

У науковій літературі з'явилася інформація за результатами досліджень про накопичення та збереження в органах і тканинах антибіотиків після забою тварин. Ці негативні сторони при використанні антибіотиків спонукають виробників тваринницької продукції шукати нові препарати для стимулювання росту й розвитку курчат-бройлерів, замість заборонених в Європі кормових антибіотиків.

У зв'язку з цим у нас в країні й за кордоном збільшилися дослідження з вивчення і створення препаратів, альтернативних антибіотиків. До них можна віднести пробіотики й ферментні препарати.

Введення пробіотиків у технологію вирощування молодняка - найбільш сучасний спосіб профрілактики шлунковокишкових захворювань, заснований на екологічно безпечних механізмах підтримки високого рівня колонізаційної резистентності кишечника. Використання фрерментних препаратів здатне підвищити кількість корисних бактерій у кишечнику, надають позитивну дію на гнильні й умовно-патогенні мікроорганізми шлунково-кишкового тракту, а також поліпшують склад мікрофрлори травного тракту (Isolauri et al., 2001; Czap \& Orishhuk, 2015).

Дослідження, спрямовані на вивчення впливу кормових дріжджів препарату як окремо, так і при комплексному використанні у складі пробіотичного комплексу на продуктивність й якісні показники м'яса курчат-бройлерів, є актуальними, становлять великий науковий та практичний інтерес.

Доведено, що введення їх до раціону курчат-бройлерів сприяє підвищенню продуктивності та покращенню перетравності поживних речовин раціону

Ключові слова: курчата-бройлери, раціон, дріжджі Saccharomyces cerevisiae, продуктивність, прирости маси, перетравність.

DOI: https://doi.org/10.32845/bsnau.Ivst.2020.2.9.

Вступ. Для успішного вирішення проблеми продовольчої безпеки країни велике значення надається птахівництву, як найбільш скоростиглої галузі тваринництва. В даний час багато сільськогосподарських підприємств не завжди можуть забезпечити достатні умови, що відповідають біологічним потребам вирощування птиці, що всіляко сприяє виникненню стресів (Lenkova et al., 2013).

Найбільш чутливою до різноманітних стресів $є$ птиця 3 високою продуктивністю, яка відрізняється високою інтенсивністю росту та рівнем обміну речовин, подібними властивостями володіють практично всі курчата-бройлери сучасних кросів (Anadyn et al., 2006).

За короткий проміжок часу в період з добового до 6-7 тижневого віку, жива маса курчат-бройлерів збільшується в 50-60 разів. Інтенсивна діяльність всіх органів і механізмів, що регулюють захисні функції організму, обумовлюється підвищеним обміном речовин у бройлерів, що сприяє зниженню стійкості організму до дії навіть незначних факторів навколишнього середовища у високопродуктивної птиці. Цим і пояснюється відносно невисока резистентність, а

також схильність захворювань, які можуть бути викликані патогенними і умовно-патогенними збудниками (Anty'pov, 2008; Tulyakova et al. 2004; Orischuk et al., 2017).

3 метою зміцнення природної резистентності птиці, підвищення її стійкості до стресів, зниження негативних наслідків антибіотикотерапії та інших необхідних технологічних прийомів, поліпшення травлення, підвищення продуктивності та збереження рекомендується застосовувати ефективні пробіотичні препарати (Bokun, 2004; Gruzauskas , 2007).

Постановка проблеми. Аналіз останніх досліджень. В умовах інтенсифікації виробництва м'яса птиці необхідно звертати особливу увагу на якість кормів, стан травних органів птиці, зокрема, на бактеріальну мікрофрлору шлунково-кишкового тракту (Zhy`la et al., 2011).

Пробіотичні препарати випускаються в рідкій, сухій i пастоподібній формі. Найбільш широко використовуються через свою технологічність їх сухі форми у вигляді капсул, порошків, таблеток та гранул. Суха форма дозволяє поєднувати в одному препараті кілька штамів одного виду Вісник Сумського національного аграрного університету 
бактерій або бактерії різних видів. Такі препарати зберігаються не менше одного року, чітко стандартизуються і сертифрікуються за показниками якості (Otchenashko, 2013).

Найчастіше у ветеринарії використовують препарати на основі мікроорганізмів травного тракту тварин, а саме Bifidobacterium, Lactobacillus, Bacillus, Clostridium i ін. Також використовують препарати на основі дріжджів Saccharomyces cerevisiae var. boulardii. Дріжджі не належать до нормальної мікрофллори тварин, однак володіють вираженою антагоністичною активністю щодо широкого спектра умовно-патогенних мікроорганізмів: синтезують ряд біологічно активних речовин, стимулюють ріст мікрофлори (лакто-, біфрідобактерії та ін.) і здатні забезпечувати оптимальні умови для підвищення продуктивності й зміцнення здоров'я тварин (Egorov \& Kuzmenko, 2014).

Вирощування курчат-бройлерів кросу “Кобб-500” на комбікормах з введенням комплексного пробіотичного препарату 3 продуцентом фітазою та препарату з личинками комах Hermetia illucens у кількості 0,5 кг/т сприяло збільшенню середньодобового приросту живої маси курчат на 2,2 і $2,6 \%$. Середньодобовий приріст живої маси бройлерів кросу "Ross-308" де в складі комбікормів використовувався пробіотик "Субтіліс", був вище на 2,5 г, тобто 4,3\%, тоді як витрати корму на одиницю приросту були нижчими на 3,8 \%, ніж в контролі, відповідно. Випоювання бройлерам пробіотика "Субтіліс" дозволило нормалізувати мікрофлору шлунково-кишкового тракту курчат. Знизилася кількість небажаної мікрофрлори в тонкому відділі кишечника бройлерів, що сприяло достовірному підвищенню живої маси птиці в кінці вирощування, підвищення збереженості поголів'я, середньодобового приросту й зниження витрат корму на одиницю приросту (Lenkova et al., 2013).

3 огляду на вищевикладене видно, що аналіз наукових досліджень свідчить про те, що сьогодні ведеться широкий пошук та вивчення різних кормових добавок, які могли б бути джерелом повноцінного білку, а в його складі повного комплексу амінокислот для птиці. В Україні таких кормових добавок високої якості мало, а що надходить 3-за кордону відрізняється високою вартістю й часто фальсифіковані (Kaminska et al., 2009).

Тому метою наших досліджень було вивчити ефрективність використання активних дріжджів Saccharomyces cerevisiae у комбікормах курчат-бройлерів та їх вплив на продуктивність та перетравність поживних речовин раціону.

Матеріали та методи дослідження. Наукові дослідження проводили в умовах ПВФ "Агроцентр". Об'єктом дослідження були курчата - бройлери кросу "Кобб 500". Упродовж основного періоду, який тривав 42 доби, враховуючи вік курчат, виділено п'ять періодів: 0-4; 5-10; 11-23; 24-37; 38 діб і до забою, згідно зі схемою досліду (табл. 1). Згідно методики було сформовано п'ять груп по 50 голів у кожній, перша виступала контрольною, інші були дослідними. Умови вирощування та годівлі були однаковими.

Хімічний склад комбікорму, який згодовувався курчатам - бройлерам контрольної та дослідних груп був однаковий і різнився лише за вмістом дріжджів Saccharomyces cerevisiae.

Хімічний склад кормів та посліду визначили у лабораторії кафедри технології годівлі і розведення тварин ДДАЕУ за традиційними методиками зоотехнічного аналізу.

1. Схема наукового досліду

\begin{tabular}{|c|c|}
\hline \multirow{2}{*}{ Група, $n=50$} & Характер годівлі \\
\hline & Зрівняльний період - 5 діб \\
\hline I (контрольна) & Повнораціонний комбікорм (ПК) \\
\hline II - дослідна & ПК + $\quad$ 0,02 \% дріжджів Saccharomyces cerevisiae замість аналогічної кількості соєвої макухи \\
\hline III - дослідна & ПК + 0,04 \% дріжджів Saccharomyces cerevisiae замість аналогічної кількості соєвої макухи \\
\hline IV - дослідна & ОК + 0,06 \% дріжджів Saccharomyces cerevisiae замість аналогічної кількості соєвої макухи \\
\hline V-дослідна & ОК + 0,08 \% дріжджів Saccharomyces cerevisiae замість аналогічної кількості соєвої макухи \\
\hline
\end{tabular}

Раціони нормували за вмістом енергії та поживних речовин згідно рекомендацій Свеженцова А. І. (2008). Для складання раціонів визначали фактичну поживність кормів, використаних у досліді, шляхом проведення хімічного аналізу.

Під час проведення експерименту враховували споживання корму птицею кожної піддослідної групи, хімічний склад та поживність комбікормів, збереженість поголів'я, живу масу, продуктивність. Облік приростів живої маси враховували щоденно.

Результати дослідження та обговорення. Організація повноцінної годівлі курчат-бройлерів в експерименті дає можливість одержати об'єктивні результати та логічно їх обґрунтувати. Основний раціон контрольної групи був збалансований за основними поживними речовинами згідно із нормами та рекомендаціями для бройлерів кросу "Кобб 500".

Дослідні групи отримували такий же раціон, але замість частини соєвої макухи, їм згодовували висушені активні живі дріжджі Saccharomyces cerevisiae згідно зі схемою експерименту. У складі комбікорму для бройлерів I (контрольної) та II, III, IV i V дослідних груп набір та кількість інгредієнтів були однаковими, тільки змінювалася кількість соєвої макухи.

Хімічний склад комбікормів, які використовували для годівлі бройлерів контрольної та дослідних груп, був близьким і різнився за поживністю незначно.

Дріжджі Saccharomyces cerevisiae складаються 3 висушених живих дріжджових клітин Saccharomyces cerevisiae штам CNCM I-1077 (не менше 1*109 КУО/г) інкапсульованих жирними кислотами, не містить генноінженерно-модифікованих організмів.

В лабораторії НДЦ біобезпеки і екологічного контролю ресурсів АПК Дніпровського державного аграрноекономічного університету проводили хімічний та амінокислотний аналіз активних дріжджів Saccharomyces cerevisiae (табл. 2). 
2. Хімічний склад активних дріжджів Saccharomyces cerevisiae, \%

\begin{tabular}{|l|c|}
\hline \multicolumn{1}{|c|}{ Показник } & Активні дріжджі Saccharomyces cerevisiae \\
\hline Загальна волога & 8,76 \\
\hline Сирий жир & 0,65 \\
\hline Сира клітковина & відсутня \\
\hline Сирий протеїн за методом Кельдаля & 46,77 \\
\hline за методом Барштейна & 41,64 \\
\hline Небілковий азот & 5,13 \\
\hline Сира зола & 4,77 \\
\hline Обмінна енергія, МДж/ кг СР & 362,9 \\
\hline
\end{tabular}

Результати визначення хімічного складу активних дріжджів показали, що в них міститься сирого протеїну 46,80 \% (за методом Кельдаля) та - 41,60 \% (за методом Барштейна), на небілковий азот припадало - 5,13 \%, вміст сирого жиру складав 2,96 \%.

В результаті проведених досліджень було встановлено, що рівень обмінної енергії у 1 кг активних дріжджів Saccharomyces cerevisiae складав 362,9 МДж/кг.

Збільшення обсягу виробництва продукції птахівництва та ефективності цієї галузі в цілому вимагає зміцнення кормової бази, організації науково-обірунтованої повноцінної годівлі, зниження витрат кормів шляхом їх раціонального використання та застосування біологічно активних речовин. Корми в структурі собівартості продукції птахівництва займають 60-75 \%, тому значні резерви збільшення рівня рентабельності виробництва полягають у підвищенні коефіцієнта корисної дії. Рецепт комбікорму курчатбройлерів наведений в табл. 3. Дані таблиці свідчать, що комбікорм складався із зернових кормів власного виробництва. На вуглеводисті зернові корми припадало - 59,7 \%, на протеїнові корми - 33,2 \%, решта мінеральні та вітамінні добавки.

\section{3. Рецепт комбікорму курчат-бройлерів}

\begin{tabular}{|l|c|}
\hline \multicolumn{1}{|c|}{ Показник } & \% вводу \\
\hline Пшениця & 31,67 \\
\hline Кукурудза & 28,00 \\
\hline Соєва макуха & 25,1 \\
\hline Соняшниковий шрот & 6,10 \\
\hline Кров'яне борошно & 2,00 \\
\hline Монокальційфосфат & 0,82 \\
\hline Ізісняк & 1,14 \\
\hline Лізин сульфат (55\%) & 0,49 \\
\hline Премікс (старт) & 0,50 \\
\hline Сіль поварена & 0,44 \\
\hline DL-метіонін (99 \%) & 0,33 \\
\hline L-треонін (98 \%) & 0,17 \\
\hline Холін хлорид & 0,12 \\
\hline Адсорбент мікотоксинів & 0,20 \\
\hline Кокцидіостатик & 0,045 \\
\hline Сульфат міді & 0,03 \\
\hline Фітаза + ксиланаза & 0,024 \\
\hline Кормова добавка & 0,02 \\
\hline
\end{tabular}

Організація повноцінної годівлі бройлерів у ПВФ "Агроцентр” дає можливість одержати об'єктивні результати та логічно обґрунтувати їх. Поживність комбікорму курчатбройлерів (табл. 4), була збалансована за основними поживними речовинами, згідно із нормами годівлі та рекомендаціями для кросу "Кобб-500".

В заключному рецепті курчат-бройлерів віком 38 діб і до забою вміст зерна пшениці збільшився до 48,5 \%, зерна кукурудзи до 20,0 \%, соєвого екструдату - 14,00 та соняшникового шроту - 12,70 \%. Корми тваринного походження, які містять високий рівень протеїну в складі комбікорму зменшилися: м'ясне та кров'яне борошно до 1,00 та 0,54 \% відповідно.

\begin{tabular}{|l|c|}
\multicolumn{2}{|c|}{ 4. Поживність комбікорму курчат-бройлерів } \\
\hline \multicolumn{2}{|c|}{ Поканк Одиниці виміру } \\
\hline \multicolumn{2}{|c|}{ В00 г комбікорму міститься: } \\
\hline Обмінної енергії, ккал & 263,36 \\
\hline Сирого протеїну, г & 22,00 \\
\hline Сирого жиру, г & 3,90 \\
\hline Сирої клітковини, г & 3,80 \\
\hline Кальцію, г & 1,00 \\
\hline Фосфору, г & 0,60 \\
\hline Калію, г & 0,95 \\
\hline Натрію, г & 0,18 \\
\hline Хлору, г & 0,32 \\
\hline Лізину, г & 1,38 \\
\hline Метіоніну, г & 0,67 \\
\hline Метіонін+цистин & 1,03 \\
\hline Треоніну, г & 0,97 \\
\hline Валіну, г & 1,03 \\
\hline Триптофану, г & 0,22 \\
\hline Холіну, г & 700,00 \\
\hline Вітаміну A & 14,000 \\
\hline Вітаміну D3 & 5,000 \\
\hline Вітаміну E & 80,00 \\
\hline
\end{tabular}

Проводячи аналіз поживності комбікорму курчатбройлерів у цей віковий період, можемо відзначити, що підвищився рівень омінної енергії до 280 ккал та рівень сирого протеїну до 18,0 \%. Адже нам відомо, що із збільшенням вікового періоду бройлерів, рівень обмінної енергії підвищується, тоді як рівень сирого протеїну навпаки знижується.

Починаючи із перших діб вирощування, простежується і збільшення живої маси курчат-бройлерів дослідних груп, яким додатково до основного раціону вводили активні дріжджі Saccharomyces cerevisiae.

На основі щотижневих зважувань курчат нами встановлені середньодобові прирости птиці. Якщо аналізувати динаміку живої маси курчат-бройлерів за кожну добу, то необхідно відмітити, що птиця дослідних груп, якій згодовували Saccharomyces cerevisiae мала кращі результати.

Особливо, це спостерігається з третьої доби птиці, наприклад, курчата-бройлери контрольної групи на п'яту добу мали 125,0 г, тоді як птиця IV дослідної групи вже почала їх випереджати, і мала живу масу 128,0 г, що на 3,0 г більше або 2,4\%.

Курчата-бройлери дослідних груп також переважали ровесників контрольної групи і в послідуючі вікові періоди, 
що добре прослідковується з восьмої доби життя, особливо це стосується птиці IV групи.

Курчата-бройлери мали вищі показники за живою масою у такі вікові періоди: 12, 15, 21, 22 та 26 добу і становила 347 г, 515, 969, 1063 і 1411 г проти 345 г, 498, 940, 1045 і 1320 г у контрольній групі. Птиця інших дослідних груп не мала суттєвих міжгрупових відмінностей.

Визначення показника збереженості поголів'я птиці дає змогу повноцінно оцінити повноцінність годівлі. Збереженість поголів'я курчат-бройлерів під час досліду становила 97-98\%. Втрати птиці в дослідний період не були пов'язані з пошкодженням шлунково-кишкового тракту.

Встановлено, що за період досліду найнижчий по- казник витрат корму на одиницю приросту був у дослідних групах, який в середньому становив 1,70-1,72 кг проти 1,74 кг у контролі.

Визначення перетравності поживних речовин корму та вивчення характеру обмінних процесів в організмі птиці $\epsilon$ одним 3 важливих методів оцінки кормів. Ступінь забезпечення сільськогосподарської птиці, поживними речовинами, крім наявності їх у необхідній кількості в кормосуміші, визначається і рівнем засвоюваності та використанням їх в організмі.

Проведені дослідження дали змогу виявити характер змін перетравності поживних речовин корму під впливом досліджуваних факторів, які представлені у таблиці 5.

5. Перетравність поживних речовин молодняку курчат-бройлерів, \% (n=3, $\bar{X} \pm S_{\bar{X}}$ )

\begin{tabular}{|c|c|c|c|c|c|}
\hline \multirow{3}{*}{ Показник } & \multicolumn{5}{|c|}{ Група } \\
\hline & \multirow{2}{*}{$\frac{\text { Контрольна }}{\mathrm{I}}$} & \multicolumn{4}{|c|}{ Дослідна } \\
\hline & & II & III & IV & V \\
\hline Суха речовина & $68,4 \pm 0,20$ & $68,8 \pm 0,15$ & $69,1 \pm 0,15$ & $71,0 \pm 0,59$ & $69,4 \pm 0,32$ \\
\hline Сирий протеїн & $69,2 \pm 0,38$ & $70,7 \pm 0,30^{*}$ & $71,6 \pm 0,28^{*}$ & $76,3 \pm 0,37^{* *}$ & $71,0 \pm 0,52^{*}$ \\
\hline Сира клітковина & $20,0 \pm 0,56$ & $20,4 \pm 0,23^{*}$ & $21,1 \pm 0,67^{*}$ & $21,6 \pm 0,75^{\star *}$ & $20,4 \pm 0,49^{*}$ \\
\hline Сирий жир & $58,3 \pm 0,83$ & $59,1 \pm 0,50$ & $59,4 \pm 0,65$ & $60,3 \pm 0,68^{*}$ & $59,7 \pm 0,56^{*}$ \\
\hline
\end{tabular}

Примітка: * $-P<0,05 ;{ }^{* *}$ - $P<0,01$ порівняно до контролю.

У складних процесах обміну речовин між організмом і зовнішнім середовищем головне місце належить білковому обміну. Це пояснюється перш за все специфічними фізикохімічними і біологічними властивостями, які характеризують їх як носіїв життя, а також тим, що вони складають структурні елементи клітин і в кінцевому підсумку визначають продуктивність сільськогосподарської птиці.

Встановлено, що використання у годівлі курчатбройлерів дослідних груп комбікормів збагачених дріжджями Saccharomyces cerevisiae сприяє кращому засвоєнню основних поживних речовин корму.

Доведено, що бройлери дослідних груп краще перетравлювали суху речовину корму, що вказує на ефективну дію Saccharomyces cerevisiae в загальному обміні речовин. Слід зазначити, що бройлери інших дослідних груп за цим показником також мали перевагу над контрольною групою.

За перетравністю сирого протеїну курчата-бройлери четвертої дослідної групи переважали не тільки контрольну групу на 7,1 \%, а і інші дослідні групи - другу на 5,6 \%, третю на $4,7 \%$, п'яту на $5,3 \%$.

Перетравність сирого жиру також була вище у бройлерів четвертої групи порівняно з першою контрольною групою на 2,0 \%, на 1,2 \% з другою, на 0,9 \% з третьою та на 0,6 \% з п'ятою дослідною групою. За перетравністю клітковини перевага четвертої групи складала 1,6 \% порівняно 3 контрольною групою, на 1,2 \% з другою дослідною групою,
0,5 \% з третьою та 1,2 \% порівняно 3 п'ятою дослідною групою.

Враховуючи вищезазначене можна констатувати, що застосування дріжджах Saccharomyces cerevisiae у комбікормах курчат-бройлерів сприяє підвищенню перетравності поживних речовин в організмі птиці.

Таким чином, пробіотичні препарати у вигляді кормової добавки набувають все більшого застосування при вирощуванні птиці як з лікувальною, так і профілактичною метою. Ринок препаратів цієї групи активно розвивається і наповнюється щораз новими зразками вітчизняного та іноземного виробництва.

Висновки.

1. Результати проведених досліджень показали, що введення активних дріжджів Saccharomyces cerevisiae до раціонів курчат-бройлерів сприяли збільшенню середньодобових приростів живої маси, за весь період вирощування найвищий середньодобовий приріст живої маси відмічено у курчат IV дослідної групи.

2. Встановлено, що додавання пробіотичної добавки в раціони птиці м'ясного напряму продуктивності позитивно вплинуло на перетравність поживних речовин. Так, у бройлерів дослідних груп спостерігалися вищі коефіцієнти перетравності сирого протеїну на 4,7-7,1\%, сирого жиру на 0,6-2,0\%, сирої клітковини на - 0,5-1,6\% у порівнянні 3 контрольною групою.

\section{Список використаної літератури:}

1. Антипов В. А. Использование пробиотиков в животноводстве. Ветеринария. 2008. Вип. 4, С. 55-58.

2. Бокун А. А. Применение пробиотиков в животноводстве. Птицеводство. 2004. Вип. 6, С. 11-15.

3. Егоров Б. В., Кузьменко Ю. Я. Роль пробиотиков в кормлении животных и сельскохозяйственной птицы. Збірник наукових праць молодих учених, аспірантів та студентів ОНАХТ. Одеса, 2014, С.27-29.

4. Жила И. И., Коцюмбас И. Я., Шкиль М. И. Морфологические исследования органов иммунной системы цыплятбройлеров при клиническом испытании эфффективности пробиотика. Материалы XVII Всероссийской научно-методической конференции по патологической анатомии животных, 2011, С.141-144.

5. Камінська М. В., Колісник Г.В., Борецька Н.І. Дія біомаси дріжджів Saccharomyces cerevisiae та Phaffia rhodozyma на склад мікробіоценозу кишечника японських перепелів. Ветеринарна біотехнологія, 2009. Вип.15, С.134-137.

6. Ленкова Т. Н., Егорова Т. А., Меньшенин И. А. Новый пробиотик А2. Птицеводство, 2013. Вип. 4, С. 23-26.

Вісник Сумського національного аграрного університету 
7. Матросова Ю. В. Эфффективность использования пробиотиков в кормлении птицы. Известия Оренбургского государственного аграрного университета, 2011, Вип. 4 (32-1), С.184-186.

8. Отченашко В.В. Пробіотики - альтернативний спосіб вирішення проблем птахівництва. [електронний ресурс], 2013.

9. Оріщук О. С., Цап С.В., Іжболдіна О.О. Ефективність використання активних дріжджів у годівлі птиці на якісні показники яець. Збірник наукових праць БНАУ. Біла Церква, 2019. Вип. 2(150), С. 64-71.

10. Orischuk O., Tsap S., Ruban N., Khmeleva E. Use of feed additives on the palm fat base in feeding of laying hens. 36ipник наукових праць Вінницького національного аграрного університету. Аграрна наука та харчові технології. 2017. Вип. 2(96), C. $67-72$.

11. Тулякова Т. В., Пасхин А. У. Седов В. Ю. Дрожжевые екстракти. Харчова промисловість. 2004. Вип. 6, С. 591 594.

12. Цап С. В., Оріщук О. С. Вплив комплексних кормових добавок з введенням пальмового жиру на продуктивність та гістологічну будову печінки бройлерів. Збірник наукових праць БНАУ. 2015. Вип. №2 (120) , С. 165-168.

13. Anadyn A., Martonez-Larranaga M., Aranzazu-MartHnez M. Probiotics for animal nutrition in the European Union. Regulation and Safety Assessment. Regulatory Toxicology. Pharmacology, 2006. C. 45.

14. Gruzauskas R., Raceviciute-Stupeliene A., Sasyte V., Semaskaite A., Miezeliene A., Alencikiene G., Tevelis V., Gimbutas A. Effects of enzymes, organic acids mixture and prebiotics on productivity of broiler chickens and sensory attributes of the meat. Veterinarija ir zootechnika. Lietuvos veterinarijos akademija. - Kaunas, 2007. issue. 37 (59), C. 13-19.

15. McFarland L., Bernasconi P. Saccharomyces boulardii: a review of an innovative biotherapeutic agent // Microb. Ecol. Health Dis, 6, 2003. C. 157-171.

16. Orishchuk O.S., Tsap S.V., Chernenko O.M., Darmogray L.M., Chernenko O.I., Mykytiuk V.V. Environmental justification forusing of active yeast in laying hens diet. Ukrainian Journal of Ecology, 2019. issue 9(2), C .189-194.

\section{References:}

1. Antypov, V. A., 2008. Yspolzovanye probyotykov v zhyvotnovodstve. [Veterinary]. Issue. 4, pp. 55-58.

2. Bokun, A. A., 2004. Prymenenye probyotykov v zhyvotnovodstve [Poultry]. Issue. 6, pp. 11-15.

3. Ehorov, B. V. and Kuzmenko, Yu. Ya., 2014. Rol probyotykov v kormlenyy zhyvotnыkh y selskokhoziaistvennoi ptytsы [Collection of scientific works of young scientists, graduate students and students of ONAHT]. - Odesa. pp. 27-29.

4. Zhyla, Y. Y., Kotsiumbas, Y. Ya and Shkyl, M. Y., 2011. Morfolohycheskye yssledovanyia orhanov ymmunnoi systemb tsupliat-broilerov pry klynycheskom yspbtanyy sffektyvnosty probyotyka [Materials of the XVII All-Russian Scientific and Methodological Conference on Animal Pathological Anatomy], pp. 141-144.

5. Kaminska, M. V., Kolisnyk, H.V. and Boretska, N.I, 2009. Diia biomasy drizhdzhiv Saccharomyces cerevisiae ta Phaffia rhodozyma na sklad mikrobiotsenozu kyshechnyka yaponskykh perepeliv [Veterinary biotechnology]. Issue.15, pp. 134-137.

6. Lenkova, T. N., Ehorova, T. A. and Menshenyn, Y. A., 2013. Novbli probyotyk A2 [Poultry]. Issue 4, pp. 23-26.

7. Matrosova, Yu. V., 2011. Эffektyvnost yspolzovanyia probyotykov v kormlenyy ptytsы. Yzvestyia Orenburhskoho hosudarstvennoho ahrarnoho unyversyteta. Issue. 4 (32-1), pp. 184-186.

8. Otchenashko, V. V., 2013. Probiotyky - alternatyvnyi sposib vyrishennia problem ptakhivnytstva. [elektronnyi resurs].

9. Orishchuk, O. S., Tsap, S. V. and Izhboldina, O. O., 2019. Efektyvnist vykorystannia aktyvnykh drizhdzhiv u hodivli ptytsi na yakisni pokaznyky yaiets [Collection of scientific works of BNAU]. Bila Tserkva. Issue. 2(150), pp. 64-71.

10. Orischuk, O., Tsap, S., Ruban, N. and Khmeleva, E., 2017. Use of feed additives on the palm fat base in feeding of laying hens [Collection of scientific works of Vinnytsia National Agrarian University. Agricultural science and food technology]. Vinnytsia. Issue. 2(96), pp. 67-72.

11. Tuliakova, T. V., Paskhyn, A. U. and Sedov, V. Yu., 2004. Drozhzhevbe ekstrakty. [Food Industry]. Issue. 6, pp. 591594.

12. Tsap, S. V. and Orishchuk, O. S., 2015. Vplyv kompleksnykh kormovykh dobavok z vvedenniam palmovoho zhyru na produktyvnist ta histolohichnu budovu pechinky broileriv. [Collection of scientific works of BNAU]. Bila Tserkva. Issue. №2 (120), pp. 165-168.

13. Anadyn, A, Martonez-Larranaga, M. and Aranzazu-MartHnez, M., 2006. Probiotics for animal nutrition in the European Union. Regulation and Safety Assessment. Regulatory Toxicology. Pharmacology. Pharmacology. p. 45.

14. Gruzauskas, R., Raceviciute-Stupeliene, A., Sasyte, V., Semaskaite, A., Miezeliene, A., Alencikiene, G., Tevelis, V. and Gimbutas, A., 2007. Effects of enzymes, organic acids mixture and prebiotics on productivity of broiler chickens and sensory attributes of the meat. Veterinarija ir zootechnika. Lietuvos veterinarijos akademija. Kaunas. Issue. 37 (59), pp. 13-19.

15. McFarland, L. and Bernasconi, P., 2003. Saccharomyces boulardii: a review of an innovative biotherapeutic agent // Microb. Ecol. Health Dis, 6. pp. 157-171.

16. Orishchuk, O.S. Tsap, S.V., Chernenko, O.M., Darmogray, L.M., Chernenko, O.I. and Mykytiuk, V.V., 2019. Environmental justification forusing of active yeast in laying hens diet. Ukrainian Journal of Ecology. issue 9(2), pp .189-194.

O.S. Orishchuk, PhD in Agricultural Sciences, Associate Professor

S.V. Tsap, PhD in Agricultural Sciences, Associate Professor

Dnipro state agrarian and economic university

Productivity of chicken broilers for introduction of saccharomyces cerevisiae yeast in fodder feed

Currently, there is a problem of obtaining environmentally friendly products that do not harm people. 
For many years, the main means of controlling the intestinal microflora of birds were feed antibiotics. However, they have a number of significant disadvantages, in particular, the ability to accumulate their residual amounts in poultry products and the development of resistance and adaptation of microorganisms to these drugs as a result of their long-term use.

Information has emerged in the scientific literature based on research on the accumulation and storage of antibiotics in organs and tissues after slaughter. These negative aspects of the use of antibiotics encourage livestock producers to look for new drugs to stimulate the growth and development of broiler chickens, instead of banned in Europe feed antibiotics.

As a result, we have increased research in the country and abroad on the study and development of drugs, alternative antibiotics. These include probiotics and enzyme preparations.

The introduction of probiotics in the technology of growing young animals is the most modern way of prevention of gastrointestinal diseases, based on environmentally friendly mechanisms to maintain a high level of colonization resistance of the intestine. The use of enzyme preparations can increase the number of beneficial bacteria in the intestine, have a positive effect on putrefactive and opportunistic microorganisms of the gastrointestinal tract, and improve the composition of the microflora of the digestive tract (Isolauri et al., 2001; Czap \& Orishhuk, 2015).

Studies aimed at studying the effect of feed yeast drug, both individually and in combination with a probiotic complex on the productivity and quality of broiler meat, are relevant, of great scientific and practical interest.

It is proved that their introduction into the diet of broiler chickens helps to increase productivity and improve the digestibility of nutrients in the diet.

Key words: broiler chickens, diet, yeast Saccharomyces cerevisiae, productivity, weight gain, digestibility.

Дата надходження до редакції: 04.09.2020 р. 